\title{
Conserving predators across agricultural landscapes in Colombia: habitat use and space partitioning by jaguars, pumas, ocelots and jaguarundis
}

\author{
Valeria Boron, Panteleimon Xofis, Andres Link \\ ESTEBAN PAYAN and Joseph TZANOPOULOS
}

\begin{abstract}
Loss and degradation of natural habitats continue to increase across the tropics as a result of agricultural expansion. Consequently, there is an urgent need to understand their effects, and the distribution and habitat requirements of wildlife within human-modified landscapes, to support the conservation of threatened species, such as felids. We combined camera trapping and land cover data into occupancy models to study the habitat use and space partitioning by four sympatric felid species in an agricultural landscape in Colombia. Land use in the area includes cattle ranching and oil palm cultivation, the latter being an emerging land use type in the Neotropics. Factors determining species occupancy were the presence of wetlands for jaguars (positive effect); water proximity for pumas (positive effect); and presence of pastures for ocelots and jaguarundis (negative effect). Only ocelots were occasionally recorded in oil palm areas. Our results suggest that to align development with the conservation of top predators it is crucial to maintain areas of forest and wetland across agricultural landscapes and to restrict agricultural and oil palm expansion to modified areas such as pastures, which are of limited conservation value. Because there is no spatial segregation between the felid species we studied, conservation strategies that benefit all of them are possible even in modified landscapes.
\end{abstract}

Keywords Camera trap, Herpailurus yagouaroundi, Leopardus pardalis, object oriented image analysis, occupancy, oil palm, Panthera onca, Puma concolor

VALERIA BoRoN* (Corresponding author) School of Anthropology and Conservation, Durrell Institute of Conservation and Ecology, Marlowe Building, University of Kent, Canterbury, Kent CT2 7NR, UK

E-mail valeria.boron@gmail.com

Panteleimon Xofis Hellenic Agricultural Organization Demeter, Forest Research Institute, Vasilika Thessaloniki, Greece

ANDRES LinK School of Management and Department of Biological Sciences, Universidad de Los Andes, Bogotá, Colombia

Esteban Payan Panthera Colombia, Cali, Colombia

Joseph TZanopoulos Kent's Interdisciplinary Centre for Spatial Studies, University of Kent, Canterbury, UK

*Also at: School of Anthropology and Conservation, Durrell Institute of Conservation and Ecology, University of Kent, UK

Received 11 October 2017. Revision requested 10 January 2018.

Accepted 14 February 2018. First published online 4 October 2018.
Supplementary material for this article is available at https://doi.org/10.1017/So030605318000327

\section{Introduction}

T abitat loss and degradation, largely driven by agricul1 tural expansion, are major threats to biodiversity (Foley et al., 2005; Maxwell et al., 2016). Consequently, there is an urgent need to reconcile agricultural expansion with the conservation of threatened species, including felids. This is particularly true in tropical regions, which are experiencing considerable land cover change and are a priority for carnivore conservation (Gibbs et al., 2010; Laurance et al., 2014; Di Minin et al., 2016). Wild felids, like other carnivores, exert important functions in the ecosystems they inhabit: by limiting the growth of herbivore populations they help to retain the structure and composition of complex biological communities (Estes et al., 2011; Ripple et al., 2014).

Protected areas are crucial for conserving high quality source habitats, but c. $90 \%$ of the geographical distribution of wild carnivores falls outside protected areas (Di Minin et al., 2016), implying that protected areas alone cannot guarantee carnivore survival in the long term. Species distribution and habitat use in unprotected and modified landscapes are largely unknown, and exploring the role of human-dominated landscapes for large-scale conservation strategies is especially important for wide-ranging carnivores. Species such as the jaguar Panthera onca and puma Puma concolor require large areas, have low reproductive rates and occur at low densities, making them particularly vulnerable to extinction (Cardillo et al., 2005; Carbone et al., 2011).

Populations of all wild felids in Neotropical forests are declining (IUCN, 2018). The Jaguar, the largest Neotropical felid, has experienced a $>50 \%$ contraction of its historical geographical distribution (Rabinowitz \& Zeller, 2010) and is currently categorized as Near Threatened on the IUCN Red List (Quigley et al., 2017), with most subpopulations at high risk of extinction (de la Torre et al., 2018). Pumas are categorized as Least Concern (Nielsen et al., 2015), but population estimates are scarce in the Neotropics (Kelly et al., 2008). Numbers of both the jaguar and puma are declining because of habitat loss, persecution and decline of 


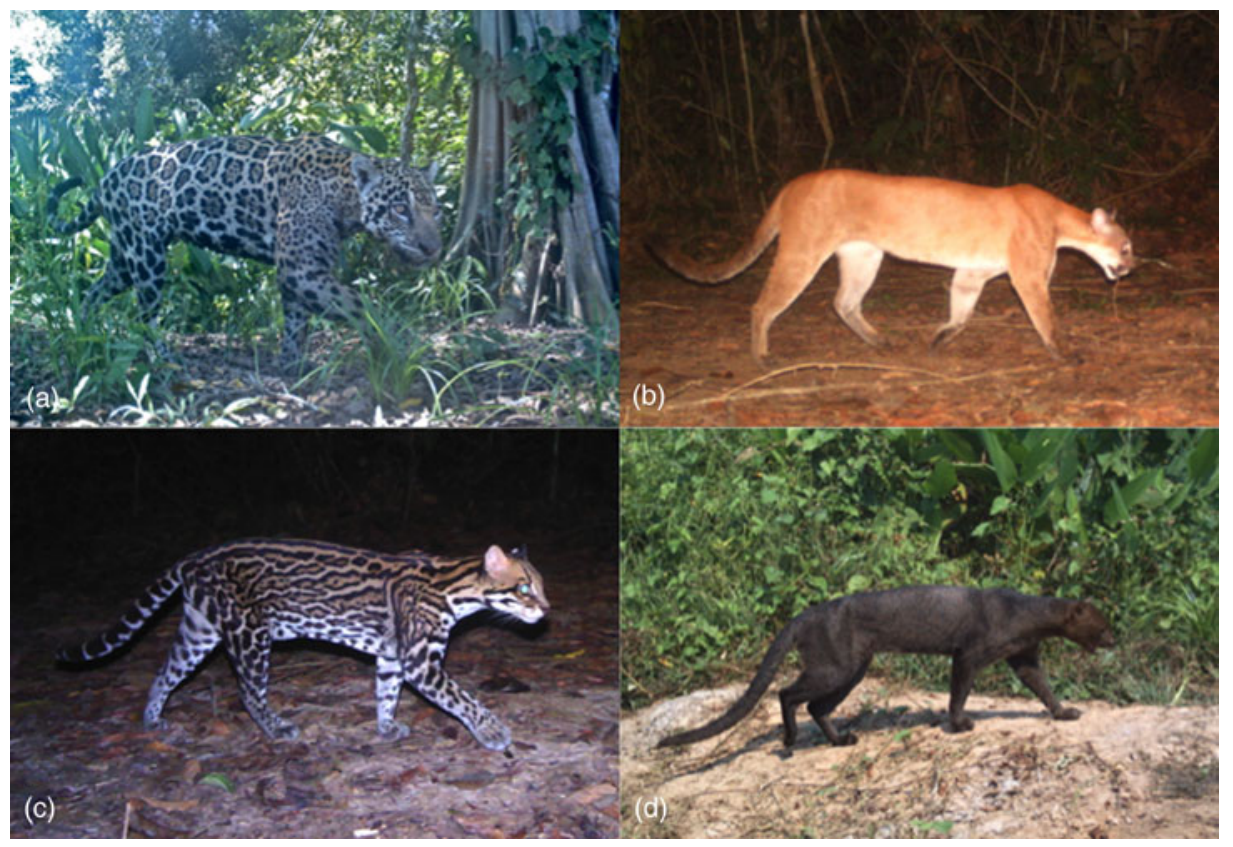

PLATE 1 Felid species recorded by camera traps across the study site in the Magdalena river valley of Colombia: (a) jaguar Panthera onca, (b) puma Puma concolor, (c) ocelot Leopardus pardalis and (d) jaguarundi Herpailurus yagouaroundi. their prey (Nielsen et al., 2015; Quigley et al., 2017), yet knowledge of their habitat use in human-modified agricultural areas is limited (Foster et al., 2010a,b; De Angelo et al., 2011, 2013). Even less is known about the ecology of smaller felids such as the ocelot Leopardus pardalis (Least Concern) and jaguarundi Herpailurus yagouaroundi (Least Concern) in agricultural landscapes (Di Bitetti et al., 2006; Kolowski \& Alonso, 2010; Giordano, 2015), yet their populations are also declining (Caso et al., 2015; Paviolo et al., 2015)

We combined high-resolution land cover maps and camera-trapping data in occupancy models to investigate the habitat use of four sympatric Neotropical felids: jaguar, puma, ocelot and jaguarundi (Plate 1) across an agricultural landscape in Colombia. The area is used for cattle ranching, the main land use in the country (Etter et al., 2006), and oil palm plantations, an emerging land use in the Neotropics (Pacheco, 2012). The latter is of particular concern for conservation because plantations constitute poor habitat for many species (Fitzherbert et al., 2008; Yue et al., 2015) and have an unknown effect on Neotropical felids. We also investigated patterns of spatial co-occurrence or avoidance between the four species. Our data will help inform strategies to align regional development with conservation actions for these predators and the diverse ecosystems they live in. This is particularly timely in Colombia, where the end of the armed conflict represents an opportunity for new developments and investments in biodiversity conservation (Baptiste et al., 2017).

\section{Study area}

We conducted the study in the central part of the Magdalena River valley in the Department of Santander,
Colombia (Fig. 1). The region is part of the tropical forest biome and is rich in wetlands (IDEAM et al., 2007), with a mean annual temperature of $27^{\circ} \mathrm{C}$ and total annual rainfall of 2,100-2,600 mm (IDEAM et al., 2007). It is considered an important genetic corridor for several species, including the jaguar, and hosts other threatened and endemic species (Payan-Garrido et al., 2013). However, the majority of the historical forest cover has been transformed into cattle ranches and oil palm plantations, and the remaining natural areas are fragmented and at risk of further conversion (Etter et al., 2006; Castiblanco et al., 2013; Link et al., 2013).

We chose our study area because it is an agricultural landscape, including cattle ranching and oil palm plantations, but still hosts top predators such as the jaguar and puma, offering opportunities to study them in an anthropogenic landscape. Land tenure in the region consists principally of private properties and there are no national protected areas. Main land cover types comprise secondary forest, wetlands, pastures, crops and oil palm plantations (Fig. 1).

\section{Methods}

\section{Camera trapping}

We placed 47 camera stations during April-August 2014, following a systematic sampling approach for camera trapping used in previous studies on Neotropical felids (Maffei \& Noss, 2008; Davis et al., 2011; Tobler \& Powell, 2013). We positioned the grid to include all main habitat types of the study area: forest (10 stations), wetland (nine stations), pasture (eight stations) and oil palm plantation (eight stations). The remaining stations were located at the edge between 


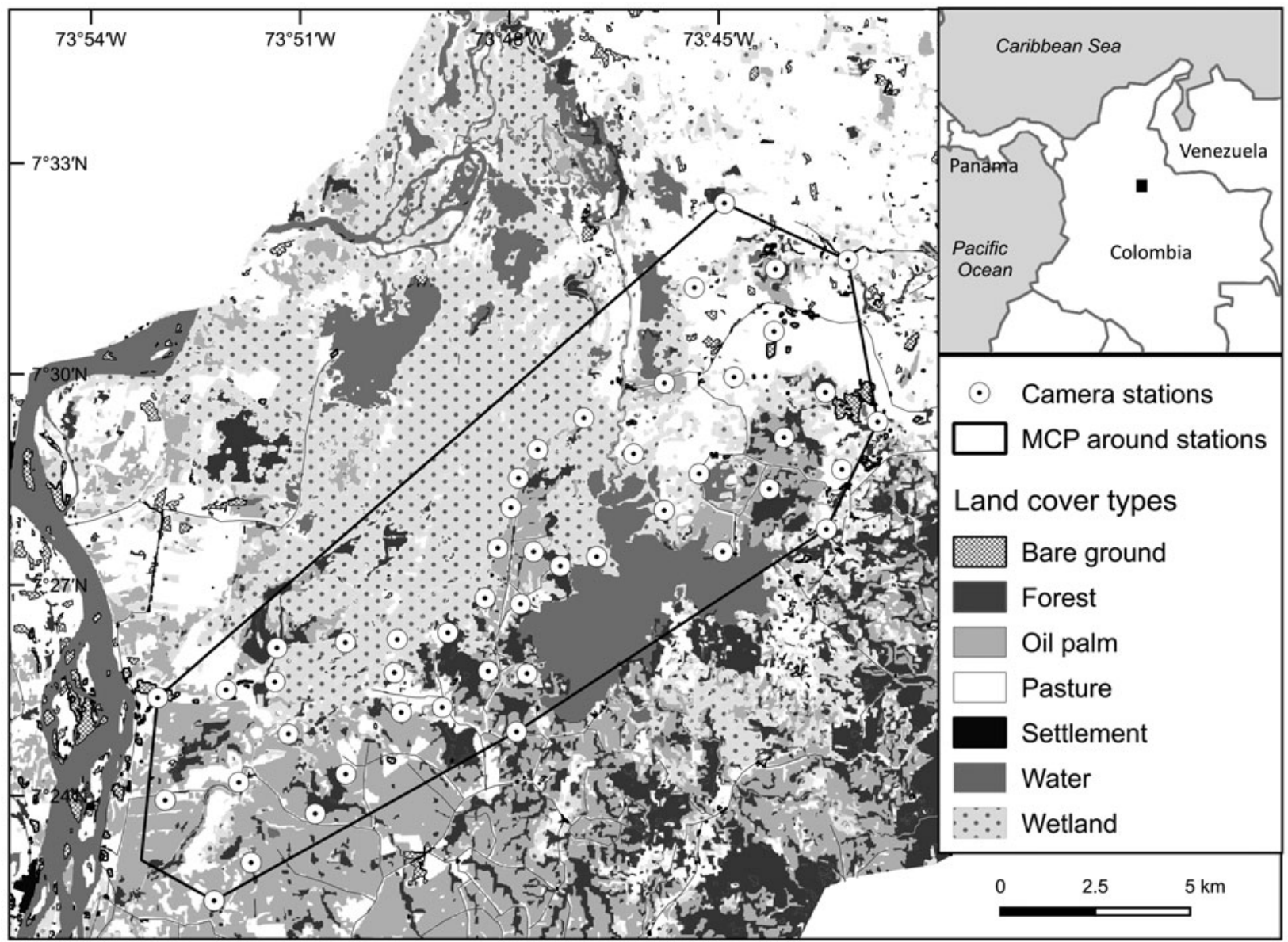

FIG. 1 Map of the study site in the Magdalena river valley of Colombia, with land cover types and camera trap stations. MCP, minimum convex polygon.

forests and oil palm plantations (six stations) and between wetlands and oil palm plantations (six stations). The minimum convex polygon around the camera stations was $154.8 \mathrm{~km}^{2}$. We placed the cameras at regular intervals of $1.6 \pm 0.3 \mathrm{~km}$ (Fig. 1), which is considered appropriate to investigate habitat use by felids (Davis et al., 2011; Sunarto et al., 2012; Everatt et al., 2015; Strampelli, 2015; Alexander et al., 2016). When we reached the appropriate distance from the previous camera, we placed the next camera within a radius of $200 \mathrm{~m}$ at a location likely to maximize felid encounters (i.e. along roads and established trails where possible). Sixty per cent of stations were placed on roads or trails and $40 \%$ away from them, a difference we took into account in the modelling. We used Attack 1149 and Ambush 1170 (both models by Cuddeback, De Pere, USA) camera traps at a height of $35 \mathrm{~cm}$ above the forest floor.

\section{Occupancy modelling to study habitat use}

We used occupancy models to investigate the potential effects of several variables on species habitat use. Such models take into account imperfect detection and use repeated presence-absence surveys (detection histories) at multiple sampling units to estimate a detection probability (P) and the true proportion of area occupied by a species $(\psi)$ (MacKenzie et al., 2006). The following assumptions are made: (1) occupancy status of the target species does not change in sampling units (i.e. they are either occupied or not for the duration of the survey), (2) species are correctly identified, (3) detections are independent, and (4) heterogeneity in occupancy or detection probability are modelled using covariates (MacKenzie et al., 2006). We conducted our analyses at the scale of the camera-trap station rather than at the home range scale and evaluated habitat use rather than the proportion of the study area occupied by each species. We defined a sampling unit as the circular area with a radius of $800 \mathrm{~m}$ around each camera station, which corresponds to half the average distance between neighbouring camera stations (Sollmann et al., 2012). We therefore interpreted $\psi$ as the intensity of use of the various sampling units and modelled both $\psi$ and $\mathrm{P}$ using predictor variables (covariates). Under these circumstances assumption (1) can be relaxed and even extensive survey lengths are not problematic (MacKenzie et al., 2006). We included covariates that have been proposed to explain habitat use $(\psi)$ by felids 
(Di Bitetti et al., 2006; Foster et al., 2010a,b; De Angelo et al., 2011; Zeller et al., 2011; Petracca et al., 2014; Giordano, 2015), considering (1) resources (hypothesized positive effect): proportion of the area covered by forests and wetlands in the sampling units, proximity to water and abundance of prey, and (2) anthropogenic pressures (hypothesized negative effect): proximity to human settlements and the proportion of sampling units covered by pastures and oil palm plantations.

\section{Land cover mapping and generation of covariates}

We identified different land cover types and their proportions across the study area, which included a buffer zone of $9.2 \mathrm{~km}$ around the camera stations. In the study area, this is the maximum distance moved by jaguars, the species with the largest home range (Nowell \& Jackson, 1996). We used object oriented image analysis on three Landsat 8 images captured on 4 January 2015, 9 March 2015 and 12 July 2015 (for further details on land cover mapping see Supplementary Material 1). We extracted the proportion of the land cover types in each sampling unit and measured the distance of each camera station from water and settlements in ArcMap 10.3 (Esri, Redlands, USA). For the jaguar and puma we also considered prey availability. These species have a wide dietary spectrum but tend to prefer larger prey species (Polisar et al., 2003; Foster et al., 2010a,b). Consequently we built two indices: one considering all prey species and another considering only prey species with a body mass $>10 \mathrm{~kg}$, which includes capybaras Hydrochoerus isthmius, white-collared peccaries Pecari tajacu and giant anteaters Myrmecophaga tridactyla. Our index of prey presence was calculated as the sum of the number of days on which a prey species was captured at each camera station, divided by the active trap days at that station (Alexander et al., 2016). We could not test prey availability for ocelots and jaguarundis because they hunt small prey such as rodents and small reptiles (Abreua et al., 2008; Giordano, 2015), which are under-detected by our camera trap methodology.

Because wild felids tend to use roads and trails (Schaller \& Crawshaw, 1980; Cusack et al., 2015), we included a categorical covariate on P ( 1 for cameras on roads or trails vs o for cameras away from roads or trails). Both camera models have the same trigger speed (0.25 s) and because of high temperatures they were triggered only at distances $<3-4 \mathrm{~m}$. We therefore did not include camera model as a covariate on $\mathrm{P}$ and assumed constant detection probability across habitats.

\section{Data analysis}

We constructed detection histories for each species and each sampling unit using unambiguously identified species photographs and grouping 14 camera trap nights into one sampling occasion. We then deployed single season single species models in PRESENCE 10.3 (Hines, 2006). Before running the models we standardized continuous covariates to $z$ scores and tested for collinearity using a cut-off value of $r=0.7$ (Dormann et al., 2013). In the first stage we defined a global model for $\psi$ and assessed whether including the covariate on $\mathrm{P}$ improved the Akaike Information Criteria adjusted for small sample size (AICc; Royle \& Nichols, 2003). We then used the best detection model and modelled all combinations of covariates for $\psi$ for each species. We included a maximum of two covariates per model, given the amount of samples to avoid over-fitting (MacKenzie et al., 2006).

We ranked models based on AICc and if there was no single model possessing a weight $\geq 0.95$ we considered models whose combined weight was $\geq 0.95$. We added the AICc weights for each covariate in the $95 \%$ CI set to evaluate their relative importance. We determined whether the influence of a covariate was positive or negative by the $\beta$ coefficient (MacKenzie et al., 2006) and employed a weighted model averaging to calculate overall estimates of $\beta$ coefficients, $\psi$ and $\mathrm{P}$ (Burnham \& Anderson, 2002). We considered covariates to have a robust effect on $\psi$ if the 95\% CIs of their $\beta$ coefficients or averaged $\beta$ coefficients did not include zero (Burnham \& Anderson, 2002; Zuur et al., 2010; Everatt et al., 2015). We assessed model fit for the global standard occupancy model by running goodnessof-fit tests with 10,000 bootstrap samples, obtaining the over-dispersion parameter $\hat{c}$ (MacKenzie \& Bailey, 2004). We repeated this process for each species.

To test for space partitioning between species, we used two-species single season occupancy models (MacKenzie et al., 2006; Sollmann et al., 2012; Sunarto et al., 2015). If two species $A$ and $B$ occur independently then the probability of occurrence of both species $\psi(\mathrm{A}$ and $\mathrm{B})=\psi(\mathrm{A}) \times \psi(\mathrm{B})$. We also determined whether $\mathrm{A}$ and $\mathrm{B}$ co-occurred more or less often than expected using $\phi=\psi(\mathrm{A}$ and $\mathrm{B}) /(\psi \mathrm{A} \times \psi \mathrm{B})$. Species co-occur more often than expected if $\phi>1$, but co-occur less often than expected if $\phi<1$, provided the $95 \%$ CIs of $\phi$ do not include 1 (MacKenzie et al., 2006).

\section{Results}

We identified seven types of land cover: pasture (35\%), wetland $(20 \%)$, oil palm plantation (19\%), forest (12\%), water $(10 \%)$, bare ground $(3 \%)$, roads and settlements $(<1 \%)$. The overall classification accuracy was 0.89 . The total sampling effort was 3,069 trap nights, and grouping 14 days into one sampling occasion resulted in 25-58 detections per felid species (Table 1). Detections of jaguars and ocelots corresponded to 12 and 21 individuals, respectively; pumas and jaguarundis could not be identified individually. No variable correlated with any of the 
TABLE 1 Best models for variables influencing occupancy $(\psi)$ and probability of detection (P) of jaguars Panthera onca, pumas Puma concolor, ocelots Leopardus pardalis and jaguarundis Herpailurus yagouaroundi across the study site in the Magdalena river valley of Colombia (Fig. 1). See Supplementary Table 2 for full model selection results. (.) indicates that no covariates were included in the model.

\begin{tabular}{|c|c|c|c|c|c|c|}
\hline & $\mathrm{AICc}^{1}$ & $\Delta \mathrm{AICc}^{2}$ & AICc weight & $\mathrm{ML}^{3}$ & $K^{4}$ & $\mathrm{LL}^{5}$ \\
\hline \multicolumn{7}{|l|}{ Jaguar (46 detections, 15 stations) } \\
\hline$\psi(\%$ wetland), P (roads) & 172.06 & 0.00 & 0.38 & 1.00 & 4 & 164.06 \\
\hline$\psi(\%$ wetland, distance to settlement), P (roads) & 173.84 & 1.78 & 0.16 & 0.41 & 5 & 163.84 \\
\hline$\psi(\%$ wetland, \% pasture), P (roads) & 173.95 & 1.89 & 0.15 & 0.39 & 5 & 163.95 \\
\hline \multicolumn{7}{|l|}{ Puma (28 detections, 14 stations) } \\
\hline$\psi($ distance to water, prey $>10 \mathrm{~kg}), \mathrm{P}$ (roads) & 158.54 & 0.00 & 0.20 & 1.00 & 5 & 148.54 \\
\hline$\psi$ (distance to water, $\%$ forest), $\mathrm{P}$ (roads) & 158.93 & 0.39 & 0.17 & 0.82 & 5 & 148.93 \\
\hline$\psi$ (distance to water, \% pasture), $\mathrm{P}$ (roads) & 159.82 & 1.28 & 0.11 & 0.53 & 5 & 149.82 \\
\hline \multicolumn{7}{|l|}{ Ocelot (58 detections, 23 stations) } \\
\hline$\psi(\%$ pasture $), \mathrm{P}$ (roads) & 259.74 & 0.00 & 0.28 & 1.00 & 4 & 251.74 \\
\hline$\psi(\%$ pasture, distance to settlement), $\mathrm{P}$ (roads) & 261.05 & 1.31 & 0.15 & 0.52 & 5 & 251.05 \\
\hline$\psi(\%$ pasture, $\%$ forest), $\mathrm{P}$ (roads) & 261.26 & 1.52 & 0.13 & 0.47 & 5 & 251.26 \\
\hline \multicolumn{7}{|l|}{ Jaguarundi (25 detections, 12 stations) } \\
\hline$\psi(\%$ pasture $), \mathrm{P}()$. & 153.55 & 0.00 & 0.29 & 1.00 & 3 & 147.55 \\
\hline$\psi(\%$ pasture, $\%$ wetland $), \mathrm{P}()$. & 155.05 & 1.50 & 0.14 & 0.47 & 4 & 147.05 \\
\hline$\psi(\%$ pasture, $\%$ forest $), \mathrm{P}()$. & 155.11 & 1.56 & 0.14 & 0.46 & 4 & 147.11 \\
\hline
\end{tabular}

${ }^{1}$ Akaike's information criterion adjusted for small sample size.

${ }^{2}$ Difference in AICc between each model and the best one.

${ }^{3}$ Model likelihood.

${ }^{4}$ Number of parameters.

${ }_{5}$ log-likelihood.

TABLE 2 Estimates of $\beta$ coefficients ( \pm SE), and summed AICc weights for covariates that influenced occupancy $(\psi)$ and probability of detection $(\mathrm{P})$ of jaguars, pumas, ocelots and jaguarundis across the study site.

\begin{tabular}{|c|c|c|c|c|c|c|c|c|}
\hline \multirow[b]{2}{*}{ Variables } & \multicolumn{2}{|l|}{ Jaguar } & \multicolumn{2}{|l|}{ Puma } & \multicolumn{2}{|l|}{ Ocelot } & \multicolumn{2}{|l|}{ Jaguarundi } \\
\hline & $\beta \pm \mathrm{SE}$ & $\begin{array}{l}\text { AICc } \\
\text { weight }\end{array}$ & $\beta \pm \mathrm{SE}$ & $\begin{array}{l}\text { AICc } \\
\text { weight }\end{array}$ & $\beta \pm \mathrm{SE}$ & $\begin{array}{l}\text { AICc } \\
\text { weight }\end{array}$ & $\beta \pm \mathrm{SE}$ & $\begin{array}{l}\text { AICc } \\
\text { weight }\end{array}$ \\
\hline$\psi . \%$ wetland & $2.91 \pm 1.25^{\star}$ & 0.97 & $0.02 \pm 0.45$ & 0.11 & $-0.02 \pm 0.40$ & 0.15 & $0.45 \pm 0.40$ & 0.19 \\
\hline$\psi . \%$ pasture & $-0.31 \pm 0.99$ & 0.15 & $-0.97 \pm 0.58$ & 0.27 & $-1.24 \pm 0.50^{*}$ & 0.89 & $-1.96 \pm 0.64^{*}$ & 0.91 \\
\hline$\psi . \%$ oil palm & & & $0.34 \pm 0.54$ & 0.08 & $0.31 \pm 0.44$ & 0.14 & $-0.17 \pm 0.41$ & 0.14 \\
\hline$\psi . \%$ forest & & & $0.81 \pm 0.53$ & 0.19 & $0.39 \pm 0.42$ & 0.18 & $0.43 \pm 0.39$ & 0.18 \\
\hline$\psi$. distance to water & $-0.15 \pm 0.74$ & 0.14 & $-1.20 \pm 0.60^{*}$ & 0.64 & $0.02 \pm 0.39$ & 0.11 & $0.09 \pm 0.44$ & 0.11 \\
\hline $\begin{array}{l}\psi \cdot \text { distance to } \\
\text { settlement }\end{array}$ & $0.57 \pm 0.61$ & 0.16 & & & $0.34 \pm 0.43$ & 0.15 & $0.04 \pm 0.39$ & 0.11 \\
\hline$\psi \cdot$ prey $>10 \mathrm{~kg}$ & $0.02 \pm 0.55$ & 0.14 & $0.80 \pm 0.51$ & 0.30 & not tested & not tested & not tested & not tested \\
\hline$\psi \cdot$ prey & & & $0.53 \pm 0.47$ & 0.10 & not tested & not tested & not tested & not tested \\
\hline P. roads & $3.14 \pm 1.12^{*}$ & 0.97 & $2.27 \pm 0.76^{\star}$ & 0.95 & $0.87 \pm 0.43^{\star}$ & 0.96 & & \\
\hline
\end{tabular}

${ }^{*}$ Covariates with robust impact $(\beta \pm 1.96 \times \mathrm{SE}$ does not include zero).

others $(r<0.7)$. Of the 12 jaguars recorded, four are resident individuals that have been in the area since 2012 (Panthera, unpubl. data).

Jaguar occupancy was strongly affected by the proportion of wetland in a sampling unit (positive effect; Tables 1, 2). Puma occupancy was best explained by the distance to water (robust negative effect), availability of prey $>10 \mathrm{~kg}$ (positive effect), proportion of pasture (negative effect), and forest (positive effect; Tables 1, 2). Ocelots and jaguarundis were strongly and negatively affected by pastures (Tables 1, 2). With the exception of ocelots, no other species was recorded in oil palm areas (Supplementary Table 1).

Cameras placed on roads or established trails were more likely to detect jaguars, pumas and ocelots (Table 2) and including this covariate for $\mathrm{P}$ improved models for these species. These cameras were also the only ones to detect jaguarundis, but we could not include it as a covariate on $\mathrm{P}$ because the model did not converge. Full model selection results for the four species are in Supplementary Table 2.

The goodness-of-fit test for global standard occupancy models for all species indicated no over-dispersion, with 
TABLE 3 Model-averaged estimates of probability of site use $(\psi)$, probability of detection (P), and associated standard errors for jaguars, pumas, ocelots, and jaguarundis across the study site.

\begin{tabular}{lll}
\hline & $\psi \pm \mathrm{SE}$ & $\mathrm{P} \pm \mathrm{SE}$ \\
\hline Jaguar & $0.42 \pm 0.10$ & $0.26 \pm 0.04$ \\
Puma & $0.45 \pm 0.14$ & $0.25 \pm 0.05$ \\
Ocelot & $0.55 \pm 0.11$ & $0.32 \pm 0.06$ \\
Jaguarundi & $0.27 \pm 0.09$ & $0.35 \pm 0.06$ \\
\hline
\end{tabular}

TABLE 4 Species interaction factors $(\phi)$ between pairs of felid species across the study site.

\begin{tabular}{lll}
\hline & $\phi \pm$ SE & $95 \%$ CI \\
\hline Jaguar \& puma & $1.93 \pm 0.33^{\star}$ & $1.38-2.69$ \\
Jaguar \& ocelot & $0.93 \pm 0.27$ & $0.53-1.63$ \\
Jaguar \& jaguarundi & $0.91 \pm 0.58$ & $0.26-3.21$ \\
Puma \& ocelot & $1.01 \pm 0.36$ & $0.50-2.03$ \\
Puma \& jaguarundi & $2.05 \pm 0.72^{\star}$ & $1.03-4.07$ \\
Ocelot \& jaguarundi & $1.47 \pm 0.27^{\star}$ & $1.02-2.12$ \\
\hline
\end{tabular}

${ }^{*}$ Strong interactions (CIs do not include 1 ).

$\hat{c}$ values close to 1 and $\mathrm{P}$ values $>0.05$ (jaguar: $\hat{c}=0.90$, $\mathrm{P}=0.77$; puma: $\hat{c}=1.10, \mathrm{P}=0.24$; ocelot: $\hat{c}=1.18, \mathrm{P}=0.19$; jaguarundi: $\hat{c}=1.08, \mathrm{P}=0.29$ ). The species' mean values for $\psi$ were in the range of $0.27-0.55$, and the mean $\mathrm{P}$ values were $0.25-0.35$ (Table 3). Analyses on space partitioning indicate co-occurrence $(\phi 95 \% \mathrm{CI}>1)$ between jaguars and pumas, pumas and jaguarundis, and ocelots and jaguarundis (Table 4).

\section{Discussion}

As agriculture continues to expand, causing habitat loss and degradation across the tropics, there is an urgent need to understand how we can support felid conservation across increasingly human-dominated landscapes, which provide habitat connectivity beyond protected areas (Karanth \& Chellam, 2009; Rabinowitz \& Zeller, 2010; Boron et al., 2016b; Di Minin et al., 2016). Neotropical felid populations are declining, with important ecological consequences (Estes et al., 2011; Galetti \& Dirzo, 2013). Our results can inform strategies to reconcile development with felid conservation, showing that (1) maintaining wetland and forest areas is crucial for the conservation of felids across agricultural landscapes, (2) the expansion of oil palm plantations and agriculture is a growing threat for felids, (3) pastures have limited conservation value for felids and should be targeted for future agricultural expansion, and (4) the four felids did not display any spatial segregation and thus conservation strategies aimed to simultaneously benefit all of them are possible even in modified landscapes.

\section{Factors affecting species habitat use}

Wetlands emerged as an important habitat for jaguars and the only variable that strongly influenced their occupancy. The jaguar inhabits a variety of ecosystems but generally prefers forests and habitats dominated by water (Crawshaw \& Quigley, 1991; Nowell \& Jackson, 1996; Foster et al., 2010a, De Angelo et al., 2011, 2013; Zeller et al., 2011). The expansion of the cattle ranching and oil palm agro-industries has restricted forests to only $12 \%$ of the study area, and increased human disturbance. Important jaguar prey species such as capybaras, peccaries, tapirs Tapirus terrestris, and deer Mazama sp. (Polisar et al., 2003; Foster et al., 2010a,b) have been largely depleted by habitat loss and hunting (Rodríguez-Mahecha et al., 2006). The presence of prey species exerted no effect on jaguar occupancy, and livestock depredation is rare in the study area (VB, pers. obs.), meaning that jaguars probably use wetlands to complement their diet with aquatic prey such as caimans Caiman crocodilus and turtles Podocnemis sp. and Trachemys sp. (Da Silveira et al., 2010). Preserving wetlands is therefore crucial for jaguar survival in the region.

Pumas were strongly associated with water bodies (streams, ponds and ciénegas), avoided pastures, and their occupancy was positively affected by the presence of forest and larger prey. Their association with water could be related to their use of riparian forests as corridors (De Angelo et al., 2011), because these forests are usually the last to remain in heavily modified regions. These findings suggest that maintaining forest habitat in modified landscapes is crucial for both pumas and their prey. Pumas are considered more of a habitat generalist than jaguars and can live in close proximity to humans (Dickson \& Beier, 2007; De Angelo et al., 2011; Sollmann et al., 2012), but they can also avoid modified areas and prefer forests where these are available (Paviolo et al., 2009; Di Bitetti et al., 2010; Foster et al., 2010a; Negrões et al., 2010; Davis et al., 2011; De Angelo et al., 2011). This concurs with our findings and is probably caused by higher prey availability in forests compared to modified areas.

Ocelots and jaguarundis are sometimes regarded as ecologically flexible and more tolerant to habitat loss and degradation than the larger felids (Nowell \& Jackson, 1996; Michalski \& Peres, 2005; Di Bitetti et al., 2006; Lyra-Jorge et al., 2008; Kolowski \& Alonso, 2010). This is supported by the fact that the ocelot was the only felid species recorded in oil palm plantations, albeit rarely. There have been previous records of ocelots using oil palm areas (Boron \& Payan, 2013; Pardo \& Payan, 2015), possibly because they harbour rodent prey and hunting is facilitated by open visibility, as reported for the leopard cat Prionailurus bengalensis (Rajaratnam et al., 2007). However, both ocelots and jaguarundis were negatively and strongly affected by pastures, 
which supports earlier findings showing that they favour more natural forested habitats and avoid human disturbance (Gonzalez et al., 2003; Giordano, 2015; Massara et al., 2015).

\section{Space partitioning}

Interspecies interactions are stronger between species of similar body mass and overlapping prey preferences, and spatial, temporal, and/or diet segregation can improve coexistence (Donadio \& Buskirk, 2006). Across Latin America, puma populations tend to be smaller where jaguars are abundant and vice versa (Kelly et al., 2008; Noss et al., 2012). However, where the two are sympatric, their habitat use is similar and segregation tends to be temporal or dietary rather than spatial (Harmsen et al., 2009; Di Bitetti et al., 2010; Foster et al., 2010a,b). This agrees with our findings of spatial co-occurrence, and it is possible that segregation occurs at the dietary level, with jaguars hunting mainly aquatic prey, and pumas targeting terrestrial prey.

Mesocarnivores such as ocelots and jaguarundis can be negatively affected by top predators and succeed when larger predators are rare or absent through phenomena of mesopredator release (Crooks \& Soulé, 1999; Moreno et al., 2006). However, ocelots can also thrive in large protected areas with better habitat quality inhabited by top predators (Massara et al., 2015), and both ocelots and jaguarundis can be positively associated with jaguars and/or pumas (Di Bitetti et al., 2010; Noss et al., 2012). We found that jaguarundis tend to co-occur with both ocelots and pumas. Ocelots can negatively affect jaguarundi numbers (Oliveira et al., 2010), but spatial co-occurrence is facilitated by temporal segregation: the jaguarundi is diurnal, whereas the puma and ocelot are mostly crepuscular and nocturnal (Di Bitetti et al., 2010; Harmsen et al., 2011). Overall, the lack of spatial segregation between species in the region indicates that their distributions can overlap, thus developing conservation strategies to simultaneously benefit all of them may be possible even in modified landscapes.

\section{Methodological considerations}

We adopted a survey design that is appropriate for investigating habitat use by felids (Davis et al., 2011; Sunarto et al., 2012; Everatt et al., 2015; Strampelli, 2015; Alexander et al., 2016). Despite felids being wide-ranging, our models showed no overdispersion, suggesting that our data were not affected by spatial autocorrelation. In addition, the identification of individual jaguars and ocelots showed that adjacent cameras never recorded the same assemblage of individuals. Habitat selection takes place at a variety of spatial and temporal scales ranging from distribution and home range selection to habitat use within the home range
(Johnson, 1980; Sunarto et al., 2012; Strampelli, 2015), and thus it is important to conduct more studies to explore these differences in modified landscapes. Finally, object oriented image analysis produced highly accurate land cover maps and covariates, and occupancy models reduced bias by taking into account imperfect detection, which is especially important for elusive species such as felids.

\section{Conclusion}

Unprotected and increasingly human-modified areas are crucial for wide-ranging carnivores, and thus it is important to understand how to achieve conservation in such landscapes. This study focused on habitat use. However, to conserve predator species across human-modified areas, habitat preservation needs to be complemented by hunting limitations and conflict management (Inskip \& Zimmermann, 2009).

Pasture is the main land cover type in Colombia (Etter et al., 2006) and has limited conservation value for felids. Further studies are needed, but our results indicate that oil palm cultivation and agricultural expansion, when inevitable, should be targeted at modified areas such as pastures, to minimize the loss of natural habitats (Garcia-Ulloa et al., 2012). Concurring results have been documented for other taxa (Gilroy et al., 2015; Prescott et al., 2016). We did not find a clear effect of oil palm plantations in our models, which could be because it still covers a relatively small proportion of the landscape (19\%). Nevertheless jaguars, pumas, and jaguarundis were never detected in oil palm areas. A stronger regulatory framework could facilitate land-use planning and incentive-based approaches (e.g. tax breaks, subsidized credits, premium prices for certified products) and also encourage the preservation of natural areas within productive landscapes (Lambin et al., 2014; Boron et al., 2016a). This study can guide land-use planning in Colombia, which is particularly timely during the country's transition towards peace following 2016. Further research should explore the habitat requirements for felids and other priority species to identify natural habitat thresholds and optimal landscape configuration, thus reconciling agriculture and biodiversity conservation.

Acknowledgements Funding bodies included the Liz Claiborne and Art Ortenberg Foundation (Jaguar Research Grant administered by Panthera), Rufford Small Grants, Idea Wild and the Explorers Club. We thank A. Montes, A. Quiñones Guerrero, and L. Jaimes Rodriguez for help with data collection and processing, the Panthera office staff in Bogotá, J. Murillo and Cabildo Verde in the Magdalena river valley for logistical support, the landowners for allowing us to access their properties, R. McCrea, A. Srivathsa and P. Strampelli for advice on data analysis, and the Editor and two anonymous reviewers for their critiques.

Author contributions Data collection: VB; data processing and analysis: VB and PX; study design and writing: all authors. 


\section{Conflicts of interest None.}

Ethical standards The research complied with the Oryx Code of Conduct for authors.

\section{References}

Abreu, K.C., Moro-Rios, R.F., Silva-Pereira, J.E., Miranda, J.M.D., Jablonski, E.F. \& Passos, F.C. (2008) Feeding habits of ocelot (Leopardus pardalis) in Southern Brazil. Mammalian Biology-Zeitschrift für Säugetierkunde, 73, 407-411.

Alexander, J.S., Shi, K., Tallents, L. \& Riordan, P. (2016) On the high trail: examining determinants of site use by the Endangered snow leopard Panthera uncia in Qilianshan, China. Oryx, 50, 231-238.

Baptiste, B., Pinedo-Vasquez, M., Gutierrez-Velez, V.H., Andrade, G.I., Vieira, P., Estupiñán-SuÁrez, L.M. et al. (2017) Greening peace in Colombia. Nature Ecology \& Evolution, 1, article ID 102.

Boron, V. \& Payan, E. (2013) Abundancia de carnívoros en el agropaisaje de las plantaciones de palma de aceite del valle medio del río Magdalena, Colombia. In Plan de Conservación de Felinos del Caribe Colombiano (eds C. Castaño-Uribe, J.F. González-Maya, D. Zárrate-Charry, C. Ange-Jaramillo \& I.M. Vela-Vargas), pp. 165176. Sierra to Sea Institute, ProCAT and Fundación Herencia Ambiental Caribe, Santa Marta, Colombia.

Boron, V., Payan, E., MacMillan, D. \& Tzanopoulos, J. (2016a) Achieving sustainable development in rural areas in Colombia: future scenarios for biodiversity conservation under land use change. Land Use Policy, 59, 27-37.

Boron, V., Tzanopoulos, J., Gallo, J., Barragan, J., JaimesRodriguez, L., Schaller, G. \& Pay Án, E. (2016b) Jaguar densities across human-dominated landscapes in Colombia: The contribution of unprotected areas to long term conservation. PLOS ONE, 11, e0153973.

Burnham, K.P. \& Anderson, D.R. (2002) Model Selection and Multimodel Inference: A Practical Information-Theoretic Approach, 2nd edition. Springer, New York, USA.

Carbone, C., Pettorelli, N. \& Stephens, P. (2011) The bigger they come, the harder they fall: body size and prey abundance influence predator-prey ratios. Biology letters, 7, 312-315.

Cardillo, M., Mace, G.M., Jones, K.E., Bielby, J., BinindaEMONDS, O.R.P., SECHREST, W. et al. (2005) Multiple causes of high extinction risk in large mammal species. Science, 1067, 1239-1241.

Caso, A., de Oliveira, T. \& Carajal, S.V. (2015) Herpailurus yagouaroundi. The IUCN Red List of Threatened Species 2015, http:// dx.doi.org/10.2305/IUCN.UK.2015-2.RLTS.T9948A50653167.en.

Castiblanco, C., Etter, A. \& Aide, T.M. (2013) Oil palm plantations in Colombia: a model of future expansion. Environmental Science \& Policy, 27, 172-183.

Crawshaw, Jr, P. \& Quigley, H. (1991) Jaguar spacing, activity and habitat use in a seasonally flooded environment in Brazil. Journal of Zoology, 222, 357-370.

Crooks, K. \& Soulé, M. (1999) Mesopredator release and avifaunal extinctions in a fragmented system. Nature, 400, 563-566.

Cusack, J.J., Dickman, A.J., Rowcliffe, J.M. \& Carbone, C. (2015) Random versus game trail-based camera trap placement strategy for monitoring terrestrial mammal communities. PLos ONE, 10, eo126373.

Da Silveira, R., Ramalho, E.E., Thorbjarnarson, J.B. \& Magnusson, W.E. (2010) Depredation by jaguars on caimans and importance of reptiles in the diet of jaguar. Journal of Herpetology, $44,418-424$
Davis, M.L., Kelly, M.J. \& Stauffer, D.F. (2011) Carnivore co-existence and habitat use in the Mountain Pine Ridge Forest Reserve, Belize. Animal Conservation, 14, 56-65.

De Angelo, C., Paviolo, A. \& Di Bitetti, M. (2011) Differential impact of landscape transformation on pumas (Puma concolor) and jaguars (Panthera onca) in the Upper Paraná Atlantic Forest. Diversity and Distributions, 17, 422-436.

De Angelo, C., Paviolo, A., Wiegand, T., Kanagaraj, R. \& Di Bitetті, M.S. (2013) Understanding species persistence for defining conservation actions: A management landscape for jaguars in the Atlantic Forest. Biological Conservation, 159, 422-433.

de la Torre, J.A., Gonzalez-Maya, J.F., Zarza, H., Ceballos, G. \& Medellin, R.A. (2018) The jaguar's spots are darker than they appear: assessing the global conservation status of the jaguar Panthera onca. Oryx, 52, 300-315.

Di Bitetti, M.S., Paviolo, A. \& De Angelo, C. (2006) Density, habitat use and activity patterns of ocelots (Leopardus pardalis) in the Atlantic Forest of Misiones, Argentina. Journal of Zoology, 270, 153-163.

Di Bitetti, M.S., De Angelo, C.D., Di Blanco, Y.E. \& Paviolo, A. (2010) Niche partitioning and species coexistence in a Neotropical felid assemblage. Acta Oecologica, 36, 403-412.

Di Minin, E., Slotow, R., Hunter, L.T.B., Montesino Pouzols, F., Toivonen, T., Verburg, P.H. et al. (2016) Global priorities for national carnivore conservation under land use change. Scientific Reports, 6, 23814.

Dickson, B.G. \& Beier, P. (2007) Quantifying the influence of topographic position on cougar (Puma concolor) movement in southern California, USA. Journal of Zoology, 271, 270-277.

Donadio, E. \& Buskirk, S.W. (2006) Diet, morphology, and interspecific killing in carnivora. The American Naturalist, 167, 524-536.

Dormann, C.F., Elith, J., Bacher, S., Buchmann, C., Carl, G., CARRÉ, G. et al. (2013) Collinearity: A review of methods to deal with it and a simulation study evaluating their performance. Ecography, 36, 027-046.

estes, J., Terborgh, J., Brashares, J., Power, M., Berger, J., Bond, W. et al. (2011) Trophic downgrading of planet Earth. Science, 333, 301-306.

Etter, A., McAlpine, C., Wilson, K., Phinn, S. \& Possingham, H. (2006) Regional patterns of agricultural land use and deforestation in Colombia. Agriculture, Ecosystems \& Environment, 114, 369-386.

Everatt, K.T., Andresen, L., Somers, M.J., Everatt, K.T., Andresen, L. \& Somers, M.J. (2015) The influence of prey, pastoralism and poaching on the hierarchical use of habitat by an apex predator. African Journal of Wildlife Research, 45, 187-196.

Fitzherbert, E.B., Struebig, M.J., Morel, A., Danielsen, F., Donald, P.F. \& Phalan, B. (2008) How will oil palm expansion affect biodiversity? Trends in Ecology \& Evolution, 23, 538-545.

Foley, J., Defries, R., Asner, G.P., Barford, C., Bonan, G., Carpenter, S.R. et al. (2005) Global consequences of land use. Science, 309, 570-574.

Foster, R.J., Harmsen, B.J. \& Doncaster, C.P. (2010a) Habitat use by sympatric jaguars and pumas across a gradient of human disturbance in Belize, Biotropica, 42, 724-731.

Foster, R.J., Harmsen, B.J., Valdes, B., Pomilla, C. \& Doncaster, C.P. (2010b) Food habits of sympatric jaguars and pumas across a gradient of human disturbance. Journal of Zoology, 280, 309-318.

Galetti, M. \& Dirzo, R. (2013) Ecological and evolutionary consequences of living in a defaunated world. Biological Conservation, 163, 1-6.

Garcia-Ulloa, J., Sloan, S., Pacheco, P., Ghazoul, J. \& Koh, L.P. (2012) Lowering environmental costs of oil-palm expansion in Colombia. Conservation Letters, 5, 366-375. 
Gibbs, H.K., Ruesch, A.S., Achard, F., Clayton, M.K., Holmgren, P., Ramankutty, N. \& Foley, J.A. (2010) Tropical forests were the primary sources of new agricultural land in the 1980s and 1990s. Proceedings of the National Academy of Sciences of the United States of America, 107, 16732-16737.

Gilroy, J.J., Prescott, G.W., Cardenas, J.S., Castañeda, P.G.D.P., Sánchez, A., Rojas-Murcia, L.E. et al. (2015) Minimizing the biodiversity impact of Neotropical oil palm development. Global Change Biology, 21, 1531-1540.

Giordano, A.J. (2015) Ecology and status of the jaguarundi Puma yagouaroundi: a synthesis of existing knowledge. Mammal Review, $46,30-43$.

Gonzalez, C.A.L., Brown, D.E. \& Gallo-Reynoso, J.P. (2003) The ocelot Leopardus pardalis in north-western Mexico: ecology, distribution and conservation status. Oryx, 37, 358-364.

Harmsen, B., Foster, R., Silver, S. \& Doncaster, C.P. (2011) Jaguar and puma activity patterns in relation to their main prey. Mammalian Biology-Zeitschrift für Säugetierkunde, 76, 320-324.

Harmsen, B.J., Foster, R.J., Silver, S.C., Ostro, L.E.T. \& Doncaster, P. (2009) Spatial and temporal interactions of sympatric jaguars and pumas in a Neotropical forest. Journal of Mammalogy, 90, 612-620.

Hines (2006) PRESENCE. Software to estimate patch occupancy and related parameters. United States Geological Survey/Patuxent Wildlife Research Center, Reston, USA. Https://www.mbr-pwrc. usgs.gov/software/presence.html [accessed 6 September 2018].

IDEAM, IGAC, IAvH, Invemar, I. Sinchi \& IIAP (2007) Ecosistemas Continentales, Costeros y Marinos de Colombia. Imprenta Nacional de Colombia, Bogotá, Colombia.

Inskip, C. \& Zimmermann, A. (2009) Human-felid conflict: a review of patterns and priorities worldwide. Oryx, 43, 18-34.

IUCN (2018) The IUCN Red List of Threatened Species, v. 2018-1. Http://www.iucnredlist.org [accessed 5 July 2018].

Johnson, D. (1980) The comparison of usage and availability measurements for evaluating resource preference. Ecology, 61, $65-71$.

Karanth, U. \& Chellam, R. (2009) Carnivore conservation at the crossroads. Oryx, 43, 1-2.

Kelly, M.J., Noss, A.J., Di Bitetti, M.S., Maffei, L., Arispe, R.L., Paviolo, A. et al. (2008) Estimating puma densities from camera trapping across three study sites: Bolivia, Argentina, and Belize. Journal of Mammalogy, 89, 408-418.

Kolowski, J.M. \& Alonso, A. (2010) Density and activity patterns of ocelots (Leopardus pardalis) in northern Peru and the impact of oil exploration activities. Biological Conservation, 143, 917-925.

Lambin, E.F., Meyfroidt, P., Rueda, X., Blackman, A., Börner, J., Cerutti, P.O. et al. (2014) Effectiveness and synergies of policy instruments for land use governance in tropical regions. Global Environmental Change, 28, 129-140.

Laurance, W.F., Sayer, J. \& Cassman, K.G. (2014) Agricultural expansion and its impacts on tropical nature. Trends in Ecology and Evolution, 29, 107-116.

Link, A., De Luna, A. \& Burbano, J. (2013) Estado de conservación de uno de los primates más amenazados con la extinción: El mono araña café (Ateles hybridus). In Primates Colombianos en Peligro de Extinción (eds T. Defler, P. Stevenson, M. Bueno \& D. Guzman), pp. 90-117. Asociacion Primatologica Colombiana, Bogotá, Colombia.

Lyra-Jorge, M.C., Ciocheti, G. \& Pivello, V.R. (2008) Carnivore mammals in a fragmented landscape in northeast of São Paulo State, Brazil. Biodiversity and Conservation, 17, 1573-1580.

MacKenzie, D.I. \& Bailey, L.L. (2004) Assessing the fit of site-occupancy models. Journal of Agricultural, Biological, and Environmental Statistics, 9, 300-318.
MacKenzie, D.I., Nichols, J.D., Royle, J.A., Pollock, K.H., BAiley, L.L. \& Hines, J.E. (2006) Occupancy Estimation and Modeling: Inferring Patterns and Dynamics of Species Occurrence. Academic Press, San Diego, USA.

MAFFEI, L. \& Noss, A.J. (2008) How small is too small? Camera trap survey areas and density estimates for ocelots in the Bolivian Chaco. Biotropica, 40, 71-75.

Massara, R.L., Maria, A., Paschoal, D.O. \& Doherty, P.F. (2015) Ocelot population status in protected Brazilian Atlantic Forest. PLoS ONE, 10, eo141333.

Maxwell, S.L., Fuller, R.A., Brooks, T.M. \& Watson, J.E.M. (2016) The ravages of guns, nets and bulldozers. Nature, 536, 143-145.

Michalski, F. \& Peres, C. (2005) Anthropogenic determinants of primate and carnivore local extinctions in a fragmented forest landscape of southern Amazonia. Biological Conservation, 124, 383-396.

Moreno, R.S., Kays, R.W. \& Samudio, Jr, R. (2006) Competitive release in diets of ocelot (Leopardus pardalis) and puma (Puma concolor) after jaguar (Panthera onca) decline. Journal of Mammalogy, 87, 808-816.

Negróes, N., Sarmento, P., Cruz, J., Eira, C., Revilla, E., FONSECA, C. et al. (2010) Use of camera-trapping to estimate puma density and influencing factors in central Brazil. Journal of Wildlife Management, 74, 1195-1203.

Nielsen, C., Thompson, D., Kelly, M. \& Lopez-Gonzalez, C.A. (2015) Puma concolor (errata version published in 2016). The IUCN Red List of Threatened Species 2015, http://dx.doi.org/10.2305/IUCN. UK.2015-4.RLTS.T18868A50663436.en.

Noss, A.J., Gardner, B., Maffei, L., Cuellar, E., Montano, R, Romero-Munoz, R. et al. (2012) Comparison of density estimation methods for mammal populations with camera traps in the Kaa-Iya del Gran Chaco landscape. Animal Conservation, 15, 527-535.

Nowell, K. \& Jackson, P. (1996) Wild Cats: Status Survey and Conservation Action Plan. IUCN, Gland, Switzerland.

Oliveira, T.G., Tortato, M.A., Silveira, L., Kasper, C.B., Mazim, F.D., Lucherini, M. et al. (2010) Ocelot ecology and its effect on the small-felid guild in the lowland Neotropics. In Biology and Conservation of Wild Felids (eds D.W. Macdonald \& A.J. Loveridge), pp. 563-574. Oxford University Press, Oxford, UK.

Pacheco, P. (2012) Soybean and oil palm expansion in South America: a review of main trends and implications. CIFOR Working Paper no. 9o. Center for International Forestry Research (CIFOR), Bogor, Indonesia.

PARDo, L. \& PAyAN, E. (2015) Mamiferos de un agropaisaje de palma de aceite en las sabanas inundables de Orocue, Casanare, Colombia. Biota Colombiana, 16, 54-66.

Paviolo, A., Di Blanco, Y.E., De Angelo, C.D. \& Di Bitetti, M.S. (2009) Protection affects the abundance and activity patterns of pumas in the Atlantic Forest. Journal of Mammalogy, 90, 926-934.

Paviolo, A., Crawshaw, P., Caso, A., De Oliveira, T., Lopez-GonZales, C.A., Kelly, M. et al. (2015) Leopardus pardalis (errata version published in 2016). The IUCN Red List of Threatened Species 2015, http://dx.doi.org/10.2305/IUCN.UK.2015-4.RLTS. T11509A50653476.en.

Payan-Garrido, E., Castano-Uribe, C., Gonzalez-Maya, J.F., Valderrama-Vasquez, C., Ruiz-Garcia, C.M. \& Soto, C. (2013) Distribución y estado de conservación del jaguar en Colombia. In Grandes Felinos de Colombia (eds E. Payan \& C. Castano-Uribe), pp. 23-26. Panthera Colombia, Conservación Internacional Colombia, Fundación Herencia Ambiental Caribe and Cat Specialist Group UICN/SSC, Bogotá, Colombia.

Petracca, L.S., Ramirez-Bravo, O.E. \& Hernandez-Santin, L. (2014) Occupancy estimation of jaguar Panthera onca to assess the value of east-central Mexico as a jaguar corridor. Oryx, 48, 133-140. 
Polisar, J., Maxit, I., Scognamillo, D., Farrell, L., Sunquist, M.E. \& EISENBERG, J.F. (2003) Jaguars, pumas, their prey base, and cattle ranching: ecological interpretations of a management problem. Biological Conservation, 109, 297-310.

Prescott, G.W., Gilroy, J.J., Haugahen, T., Medina Uribe, C., Foster, W. \& Edwards, D.P. (2016) Managing Neotropical oil palm expansion to retain phylogenetic diversity. Journal of Applied Ecology, 53, 150-158.

Quigley, H., Foster, R., Petracca, L., Payan, E., Salom, R. \& Harmsen, B. (2017) Panthera onca. The IUCN Red List of Threatened Species 2017, http://dx.doi.org/10.2305/IUCN.UK.2017-3. RLTS.T15953A50658693.en.

Rabinowitz, A. \& Zeller, K. (2010) A range-wide model of landscape connectivity and conservation for the jaguar, Panthera onca. Biological Conservation, 143, 939-945.

Rajaratnam, R., Sunquist, M., Rajaratnam, L. \& Ambu, L. (2007) Diet and habitat selection of the leopard cat (Prionailurus bengalensis borneoensis) in an agricultural landscape in Sabah, Malaysian Borneo. Journal of Tropical Ecology, 23, 209-217.

Ripple, W.J., Estes, J.A., Beschta, R.L., Wilmers, C.C., Ritchie, E.G., Hebblewhite, M. et al. (2014) Status and ecological effects of the world's largest carnivores. Science, 343, 1241484.

Rodríguez-Mahecha, J.V., Alberico, M., Trujillo, F. \& Jorgenson, J. (2006) Libro Rojo de los Mamíferos de Colombia. Serie Libros Rojos de Especies Amenazadas de Colombia. Conservación Internacional Colombia, Ministerio de Ambiente, Vivienda y Desarrollo Territorial, Bogotá, Colombia.

Royle, J. \& Nichols, J. (2003) Estimating abundance from repeated presence-absence data or point counts. Ecology, 84, 777-790.

Schaller, G.B. \& Crawshaw, JR, P.G. (1980) Movement patterns of jaguar. Biotropica, 12, 161-168.
Sollmann, R., Furtado, M.M., Hofer, H., JÁcomo, A.T.A., TôrRes, N.M. \& Silveira, L. (2012) Using occupancy models to investigate space partitioning between two sympatric large predators, the jaguar and puma in central Brazil. Mammalian Biology-Zeitschrift für Säugetierkunde, 77, 41-46.

Strampelli, P. (2015) Status and Habitat use Responses of Leopard (Panthera pardus) in a Human Impacted Region of Rural Mozambique. MSc thesis. Imperial College London, London, UK.

Sunarto, S., Kelly, M.J., Parakkasi, K., Klenzendorf, S., Septayuda, E. \& Kurniawan, H. (2012) Tigers need cover: multi-scale occupancy study of the big cat in Sumatran forest and plantation landscapes. PLOS ONE, 7, e30859.

Sunarto, S., Kelly, M.J., Parakkasi, K. \& Hutajulu, M.B. (2015) Cat coexistence in central Sumatra: ecological characteristics, spatial and temporal overlap, and implications for management. Journal of Zoology, 296, 104-115.

Tobler, M.W. \& Powell, G.V.N. (2013) Estimating jaguar densities with camera traps: problems with current designs and recommendations for future studies. Biological Conservation, 159, 109-118.

Yue, S., Brodie, J.F., Zipkin, E.F. \& Bernard, H. (2015) Oil palm plantations fail to support mammal diversity. Ecological Applications, 25, 2285-2292.

Zeller, K.A., Nijhawan, S., Salom-Pérez, R., Potosme, S.H. \& Hines, J.E. (2011) Integrating occupancy modeling and interview data for corridor identification: A case study for jaguars in Nicaragua. Biological Conservation, 144, 892-901.

ZuUr, A.F., Ieno, E.N. \& Elphick, C.S. (2010) A protocol for data exploration to avoid common statistical problems. Methods in Ecology and Evolution, 1, 3-14. 